\title{
Perempuan dan Revenge Porn: Konstruksi Sosial Terhadap Perempuan Indonesia dari Preskpektif Viktimologi
}

\author{
Okamaisya Sugiyanto \\ Fakultas IImu Sosial dan IImu Politik, Universitas Sebelas Maret Surakarta \\ ${ }^{*}$ Penulis Koresponden: okamaisyasugiyanto0@gmail.com
}

\section{ABSTRAK}

Penelitian ini bertujuan untuk menggambarkan salah satu Kasus Kekerasan Berbasis Gender Online (KBGO) yaitu revenge porn dengan melihat 3 aspek. Antara lain bagaimana peranan perempuan sebagai korban dalam terjadinya revenge porn, penyebab kriminalisasi korban dan upaya perlindungan terhadap korban. Pandemi Covid-19 memaksa orang-orang untuk tinggal di dunia maya. Peningkatan jumlah penggunaan teknologi internet tersebut selaras dengan peningkatan kasus Kekerasan Berbasis Gender Online (KBGO). Komnas Perempuan mencatat terdapat 97 kasus kekerasan di dunia maya dimana 33\% diantata kategori revenge porn. Metode yang digunakan adalah deskriptif kualitatif dengan teknik pengumpulan data studi dokumentasi. Peneleti menggunakan teori viktimologi dan konstruksi sosial guna mengkaji permasalan yang ada. Ditinjau dari prespektif viktimologi perempuan dalam kasus revenge porn termasuk dalam latent victim. Selain itu tak jarang perempuan dalam kasus revenge porn kerap terkriminalisasi yang disebabkan oleh budaya patriarki yang mengakar kuat dalam masyarakat. Payung hukum yang ada pun juga tak jarang menyebabkan korban terkriminalisasi sehingga dibutuhkan payung hukum baru yang mampu melindungi korban.

Kata Kunci: KBGO; Revenge porn; Viktimologi; Konstruksi Sosial

\section{ABSTRACT}

This study aims to describe one of the cases of online gender based violence (KBGO), namely revenge porn by looking at 3 aspects. Among other things, how is the role of women as victims in the occurrence of revenge porn, the causes of criminalization of victims and efforts to protect victims. The Covid-19 pandemic is forcing people to live in cyberspace. The increase in the use of internet technology is in line with the increase in cases of Online Gender Based Violence (KBGO). Komnas Perempuan noted that there were 97 cases of violence in cyberspace, of which 33\% belonged to the revenge porn category. The method used is descriptive qualitative with data collection techniques of documentation studies. The researcher uses the theory of victimology and social construction to examine the existing problems. From the perspective of victimization, women in the case of revenge porn are included in the latent victim. In addition, it is not uncommon for women in revenge porn cases to be criminalized due to the patriarchal culture that is deeply rooted in society. The existing legal regulation also often causes victims to be criminalized so that a new legal regulation is needed that is able to protect victims.

Kata Kunci: KBGO; Revenge porn; Victimology; Social Construction

\section{PENDAHULUAN}

Dewasa ini, diskursus tentang Kekerasan Berbasis Gender Online (KBGO) menjadi topik yang banyak diperbincangkan baik oleh praktisi, akademisi, masyarakat, hingga media massa. Hal itu karena di masa pandemi Covid-19 memaksa orang-orang untuk tinggal di dunia maya guna memutus mata rantai penyebaran virus Covid-19. Penggunaan teknologi internet menjadi hal yang wajib dimiliki oleh setiap orang. Kekerasan Berbasis Gender Online (KBGO) itu sendiri merupakan salah satu modifikasi kekerasan baru di dunia cyber. Kekerasan ini merupakan salah satu serangan yang dilakukan terhadap tubuh, seksualitas serta identitas gender seseorang yang menggunakan teknologi digital sebagai fasilitasnya. Dalam panduan milik Southeast Asia Freadom of Expresion Network (SAFEnet) menyebutkan bahwa sejak tahun 2015 Komnas 
Perempuan telah memberikan catatan tentang kekerasan terhadap perempuan yang terkait dengan dunia online, dan ia mengatakan bahwa kekerasan dan kejahatan cyber saat ini memiliki pola kasus yang semakin rumit. Pada tahun 2017 Komnas Perempuan menerima setidaknya terdapat 8 bentuk Kekerasan Berbasis Gender Online antara lain pendekatan untuk memperdaya (cyber grooming), pelecehan online (cyber harassment), peretasan (hacking), konten ilegal (illegal content), pelanggaran privasi (infirngement of privacy), ancaman distribusi foto/video pribadi (mallicious distribuiton), pencemaran nama baik (online defamation) dan rekrutmen online (online recruitment). Berdasarkan CATAHU Komanas Perempuan yang mana di dalamnya terdapat 3 sumber data yang dihimpun antara lain Data Peradilan Agama (Badilag), Data Lembaga Layanan mitra baik yang dikelola negara maupun inisiatif masyarakat, dan data yang berasal dari Unit Pelayanan dan Rujukan. Temuan pada data Lembaga Penyedia Layanan menunjukan bahwa Kekerasan Berbasis Gender Online atau Siber pada tahun 2020 meningkat menjadi 510 kasus, yang mana pada tahun sebelumnya terdapat 126 kasus. Dimana KBGO ini didominasi dengan kekerasan psikis sebesar 49\% atau 491 kasus kemudian kekerasan seksual sebanyak 479 kasus atau sebesar 48\% dan kekerasan ekonomi sebesar 2\% atau sebanyak 22 kasus.

Salah satu permasalahan yang urgent untuk dikaji dan memerlukan tindakan adalah terkait dengan kasus penyebaran konten foto atau video tubuh seseorang tanpa izin. Pendistribusian konten secara non-konsensual tersebut termasuk kedalam kekerasan seksual di dunia cyber yang banyak menyerang perempuan. Pada tahun 2019 Komnas Perempuan Mencatat terdapat 97 kasus kekerasan pada perempuan di dunina maya dimana 33\% diantaranya termasuk dalam kategori revenge porn (Adinda, 2021). Matsuri menyatakan Revenge porn atau pornografi balas dendam merupakan pornografi dengan memanfaatkan kepemilikan materi pornografi yang diperoleh secara 'sah' namun disebarluaskan dengan tujuan 'balas dendam' setelah putus hubungan (Matsuri, 2015:289). Salah satu jenis Kekerasan Berbasis Gender Online (KBGO) tersebut senyatanya lebih banyak menyerang wanita dibandingkan dengan pria. Hal itu karena adanya konstruksi sosial yang menganggap bahwa wanita sebagai objek seksualitas, tubuh perempuan hanya sebatas ornamen. Tentu tidak jauh dari nalar patriarki yang menjamur di benak masyarakat kita yang menempatkan perempuan sebagai liyan. Lebih parah lagi perempuan yang notabene adalah "korban" di dalam Kekerasan Berbasis Gender Online (KBGO) kerap kali mendapat label-label buruk di dalam masyarakat. Media dan juga publik secara terang terangan membuka kehidupan pribadi korban alih-alih menjamin perlindungan terhadap data pribadi miliknya. Masyarkat justru menyudutkan posisinya dengan melakukan penghakiman terhadap moral perempuan.

Berdasarkan latar belakang tersebut maka akan memunculkan pertanyaan antara lain bagaimanakah peranan perempuan sebagai korban dalam terjadinya revenge porn? Apa yang menyebabkan kriminalisasi korban terhadap kasus revenge porn? Dan yang terakhir bagaimana upaya perlindungan korban dari kasus revenge porn? Sehingga dari rumusan masalah yang hendak dikaji tersebut peneliti mengambil judul penelitian "Perempuan dan Revenge Porn: Konstruksi Sosial Terhadap Perempuan Indonesia dari Preskpektif Viktimologi”.

\section{TINJAUAN PUSTAKA}

Menurut John M. Echols dan Hassan Shadili, Gender sering diidentikan dengan jenis kelamin (sex) senyatanya gender berbeda dengan jenis kelamin, kodrat dari Tuhan. Secara etimologis kata gender berasal dari bahasa Inggris yang berarti 'jenis kelamin'. Menurut Victoria Neufeldt kata gender bisa diartikan sebagai perbedaan yang tampak antara laki-laki dan perempuan dalam hal nilai dan 
perilaku (Marzuki, 2007:68). Sedangkan menurut Women's Studies Encyclopedia bahwa gender adalah suatu konsep kultural yang dipakai untuk membedakan peran, perilaku, mentalitas, dan karakterisitk emosional antara laki-lak dan perempuan yang berkembang dalam masyarakat (Mulia, 2004:4). Sedangkan perempuan secara etimologis berasal dari kata empu yang berarti "tuan" orang yang mahir, berkuasa, kepala, hulu, yang paling besar (Saksono, 2001). Namun dalam bukunya Zaitunah Subhan memberikan arti kata perempuan sebagai hal yang dihargai (Subhan, 2004:1).

Berdasarkan Rebeca, balas dendam porno (revenge porn) atau yang lebih dikenal sebagai pornografi balas dendam (dan bahasa sehari-hari sebagai 'sextortion'), melibatkan distribusi gambar atau video seksual eksplisit, tanpa persetujuan dari individu yang bersangkutan (Paulina, 2019:459). Sedangkan sekstorsi merupakan bentuk kekerasan berbasis gender online yang dilakukan dengan memeras korban dengan memanfaatkan foto atau video pornografi milik korban yang didapatkan baik secara hacking, maupun diberikan secara langsung oleh korban atas dasar kepercayaan dalam suatu hubungan. Foto atau video tersebut lantas disalahgunakan oleh pelaku sekstorsi dengan memberikan ancaman guna memeras materi maupun secara seksual kepada korban. Perbuatan seperti inilah yang disebut sebagai sekstorsi. Sekstorsi dan Non-Consensual Pornography (revenge porn) memang memiliki persamaan, yang menjadi pembeda mutlak dari keduanya adalah dalam kejahatan sekstorsi terdapat unsur pemerasan oleh pelaku (Christian, 2020:84).

Viktimologi berasal dari bahasa latin victim yang berarti korban dan logos yang berarti ilmu. Secara terminologi, viktimologi berarti suatu studi yang mempelajari tentang korban, penyebab timbulnya korban dan akibat-akibat penimbuan korban yang merupakan masalah manusia sebagai suatu kenyataan sosial (Mansur dan Gultom, 2007:84). Lilik Mulyadi membagi jenis korban menjadi lima yaitu (Mulyadi, 2007:124):

1. Nonparticipating victims, yaitu mereka yang tidak peduli terhadap upaya penanggulangan kejahatan.

2. Latent victims, yaitu mereka yang mempunyai sifat karakter tertentu sehingga cenderung menjadi korban.

3. Procative victims, yaitu yang menimbulkan rangsangan terjadinya kejahatan.

4. Participating victims, yaitu mereka dengan perilakunya memudahkan dirinya menjadi korban.

5. False victims, yaitu mereka yang menjadi korban karena perbuatan yang dibuatnya sendiri.

Bicara tentang konstruksi sosial (social construction), tidak lepas dari pemikiran Peter L. Berger dan Thomas Luckmann. Untuk memahami realitas, ada upaya yang terkoordinasi dan mengikuti proses pertukaran yang pemikiran yang menjadi karakteristik manusia. Makna (meaning) diproses dan dimaknai oleh pelaku sosial dengan menjadikannya sebagai realitas, yang secara terus menerus dilakukan akan menjadi realitas sosial hasil dari konstruksi makna yang dipahami oleh pelaku sosial. Asumsi yang dikembangkan oleh Peter L. Berger dan Thomas Luckmann melalui The Social Construction of Reality: A Treatise in Sociological of Knowledge adalah proses realitas sosial tidak hadir begitu saja, tetapi diterima dan dimaknai melalui sebuah proses dialektis, feedback (timbal-balik) yang berlangsung dalam waktu lama dan berulang kali terjadi antara 
pelaku sosial. Peter L. Berger dan Thomas Luckmann mengatakan bahwa antara fenomena sosial dalam pemikiran dan tindakan sosial, pada akhirnya muncul realitas sosial. Lebih jauh Peter L. Berger dan Thomas Luckmann mengatakan bahwa proses sosial tercipta melalui tindakan dan interaksi individu, dimana individu secara intens menciptakan suatu realitas yang dimiliki dan dialami bersama secara subjektif (Alfirahmi dan Ekasari, 2018:235). Konstruksi hadir melalui tindakan dan interaksi individu, secara terus menerus terhadap kenyataan (realitas) yang dimiliki dan dialami bersama dengan individu lain secara subjektif (Parera dan Frans, 1990). Makna terkonstruksi secara terus menerus, dan menjadi pijakan bagi individu dalam bertindak, dan makna inilah kemudian yang dipahami sebagai konstruksi sosial.

\section{PEMBAHASAN}

\section{Tinjauan Viktimologi Perempuan dalam Kasus Revenge Porn}

Selama pandemi Covid-19 terjadi peningkatan aktivitas masyarakat di dunia digital. Kebutuhan akan teknologi informasi dan komunikasi saat ini menjadi tulang punggung masyarakat dalam menjalankan aktivitas baik bekerja, belajar, berbelanja dan berkomunikasi. Menurut Dewan Teknologi Informasi dan Komunikasi Nasional (Wantikknas) kebutuhan jaringan internet yang yang megalami peningkatan 15\% dibandingkan traffic rata rata. Jaringan internet indihome mencatat biasanya terdapat 3-9 juta pengguna kini menjadi 11 juta. Penggunaan media sosial pun turut menjadi lonjakan pengguna. Trafic pengguna aplikasi Whatsapp dan Instagram kini naik 40\%. Berdasarkan Survei Firma Konsultan Kantr Whatsapp menjadi salah satu aplikasi yang paling sering digunakan selama pandemi dimana yang awalnya 27\% diawal pandemi kini meningkat hingga $41 \%$ di pertengahan pandemic (Wantiiknas, 2021).

Peningkatan aktivitas di dunia digital tersebut selaras dengan peningkatan jumlah kasus Kekerasan Berbasis Gender Online (KBGO). Berdasarkan data yang diunggah oleh Komnas Perempuan dalam Catatan Tahunan (CATAHU) 2020 selama 3 tahun terakhir terdapat peningkatan yang drastis. Kekerasan Berbasis Gender Online (KBGO) adalah sebuah bentuk kekerasan yang terjadi atas dasar relasi gender, antara korban dan pelaku di ranah online atau yang menggunakan teknologi digital. Serta merupakan ekstensi/perpanjangan dari kekerasan berbasis gender di ranah luring (offline). Kekerasan di ranah daring (online) secara umum dapat terjadi serta menimpa lakilaki ataupun perempuan, namun apabila ditinjau dari segi gender perempuan dinilai lebih rentan untuk menjadi korban yaitu sebesar $71 \%$.

Tubuh perempuan sekarang ini tidak aman di mana pun baik dalam dunia nyata maaupun maya. Kekerasan terhadap perempuan sering kali dinormalisasi oleh masyarakat dengannya adanya asumsi bahwa tersebarnya data-data intimnya di ranah digital secara non-konsensual adalah akibat dari kelalaian dan kecerobohan perempuan. Korban kerap dipersalahkan karena tidak berhati-hati dengan data pribadinya. Apabila ditinjau dari prespektif viktimolgi perempuan menurut jenis korban dalam (Mulyadi, 2007:124) termasuk dalam latent victim. Sejalan dengan penelitian yang dilakukan Indrawati yang menyatakan bahwa perempuan dan anak tergolong dalam latent vicitm dimana mereka secara potensial menjadi korban kejahatan (Indrawati, 2015:39). Hal lain yang memunculkan potensi menyebabkan perempuan sebagai korban dari sudut pandang psikologi perempuan dicirikan umumnya sebagai makhluk yang emosional, mudah menyerah, pasif, subjektif, mudah terpengaruh, lemah fisik. Ciri psikologi seorang perempuan apabila dilihat sebagai korban dimulai dari adanya ketakutan yang dimiliki seseorang, yang kemudian diikuti dengan sikap pasrah. Makna dari kata "pasrah" adalah menerima tindakan yang dilakukan orang 
lain terhadap dirinya sebagai sebuah nasib atas penderitaannya, di mana pemikiran ini dapat dikatakan suatu budaya fatalistik. Kondisi pasrah inilah yang nantinya akan semakin membuka potensi perempuan menjadi korban pada fase tidak berdaya, sehingga hal itu dapat menjadi potensi bagi pelaku untuk mencari keuntungan. Menurut Von Hentig kondisi ketakutan yang diikuti sikap pasrah tersbut disebabkan oleh adanya faktor biologik yang mengkategorikan perempuan sebagai korban dengan sebutan the female, sehingga perempuan sangat rentan menjadi korban karena fisiknya lebih lemah (Widiartana, 2014:131). Perempuan sebagai korban revenge porn sekaligus pemicu lahirnya kejahatan diakibatkan dari perilaku korban sendiri yang mana dikenal provocatif victims (timbulnya tindak pidana karena provokasi dari korban) berdasarkan hasil survei Straus, dkk., perempuan diposisikan berpribadi Masochist (menawarkan diri untuk korban kekerasan), memiliki harga diri yang rendah (low self esteem), sindroma ketidakberdayaan (syndrome helplessness), sehingga mudah atau cenderung menjadi korban berulang kali. Memperhatikan penjabaran di atas, serta dengan melihat realita di Indonesia maka penulis memandang perempuan dalam praktik revenge porn ini tidak semata dari perspektif pelaku, tetapi juga dari perspektif korban (Munir, dkk., 2020:30).

1. Adanya pandangan bahwa perempuan sebagai makhluk yang lemah, mudah menyerah, lemah fisik dapat memicu perempuan sebagai korbam dari revenge porn.

2. Kebanyakan korban tidak sembarang memberikan gambar atau video mereka ke orang yang tidak mereka kenal. Mereka membagikan gambar tersebut ke orang yang mereka percaya. Kasus revenge porn sendiri banyak dilakukan oleh mantan kekasih (atau pihak ketiga) yang berusaha menjatuhkan citra perempuan melalui penyebaran foto maupun video porno.

3. Penyebab lain perempuan menajdi korban adalah karena karena gambar atau video mereka diambil secara paksa, seperti komputer mereka diretas atau orang-orang terdekat mereka memaksa mengambil foto mereka.

Kasus revenge porn sendiri memiliki tujuan tidak hanya membalaskan sakit hati yang dialaminya, tetapi berdasarkan penelitian pada masalah pornografi melalui internet menunjukkan bahwa pornografi sebagai balas dendam merupakan salah satu bentuk kejahatan pornografi dengan modus operandi baru (Munir, dkk., 2020:30). Dalam kasus lain, revenge porn bisa dilakukan oleh orang yang memang berniat melakukan pencemaran nama baik atau merusak citra pihak lain, digunakan pelaku sebagai alat guna memaksa perempuan untuk melakukan sesuatu, seperti meminta uang, mengancam, dan dapat berlanjut pada kekerasan seksual.

\section{Belenggu Patriarki Akar Kriminalisasi Terhadap Korban}

Objektifikasi tubuh perempuan yang mana sebelumnya terjadi pada luar jaringan kini telah menjelma ke dalam ruang digital. Hal tersebut tentu berimplikasi pada perempuan yang diharuskan untuk selalu bersikap waspada. Seperti halnya dalam kejadian pelecehan ataupun kekerasan seksual secara luring, korban dipersalahkan (victim blaming) atas cara mereka berpakaian, berbicara, maupun membawa dirinya. Berdasarkan Richmond-Abbott, pandangan budaya kita tentang kejahatan seksual membantu melestarikan sikap menyalahkan korban (blaming the victim) dan memaklumi pelaku kejahatan serta memperkuat perbedaan kekuatan dan kekuasaan antar jenis kelamin laki-laki dan perempuan. Lebih lanjut, konsep blaming the victim menurut Ryan ialah 
tentang pembenaran atas ketidakadilan dengan menemukan cacat atau kesalahan pada korban ketidakadilan (Putri, 2012:1-5).

Dalam konsep Blaming The Victim, perempuan sebagai korban lah yang dipersalahkan, melalui kata-kata dan kalimat yang ada dalam pemberitaan media, perempuan dalam satu waktu digambarkan sebagai korban sekaligus pemicu terjadinya kejahatan yang menimpa dirinya. Disinilah relasi kuasa yang dibentuk dari budaya patriarki tersebut muncul. Ketika perempuan dianggap sebagai kaum inferior dan laki-laki sebagai kaum yang superior. Menurut BurgessProctor (2006) dalam Mustafa (2003:256), memandang patriarki (dominasi laki-laki), merupakan akar masalah dari penindasan terhadap perempuan. Perempuan mengalami diskriminasi karena relasi sosial dan interaksi sosial yang dibentuk oleh kekuasaan laki-laki (Munir, dkk., 2020:25). Obsesi pada tubuh perempuan tersebut saat ini tecermin dalam hukum, nilai budaya, politik, maupun pandangan sosial yang ada. Revenge porn atau pemerkosaan siber juga didasarkan pada motif serupa. Laki-laki yang menyebarkan foto mantan kekasihnya menikmati kekuasaan atas diri perempuan dengan melakukan kontrol terhadap tubuh perempuan tersebut.

Tak jarang kita mendengar bahwalangkah-langkah mencegah revenge porn adalah dengan, "jangan mau memberikan video privatmu ke siapa pun," atau "jangan sampai wajahmu kelihatan ketika kamu memberikan foto syur kamu ke pacar." Menyalahkan korban yang dianggap telah sembrono mengambil gambar telanjang menurut laman berita Jawapos sama dengan perilaku victim blaming. Selama ini pusat kesalahan selalu diletakkan kepada korban, ketika yang seharusnya dipermasalahkan adalah wewenang si korban yang telah direnggut. Revenge porn bukan hanya berfokus pada maslah penyebaran gambar intim di dunia digital atau cyberspace namun juga didalamnya terdapat maslah kontrol perempuan terhadap tubuh mereka yang direnggut dan dipaksa untuk hidup sebagai properti komunal (Adinda, 2021).

Gambaran ketidakadilan dan diskriminasi kaum perempuan di Indonesia dapat dilihat dari kasus penetapan salah satu public figure Indonesia GA yang dirinya dijadikan sebagai tersangka oleh polisi dengan menggunakan dasar hukum UU No. 44 tahun 2008 tentang Pornografi. UU Pornografi, UU ITE (Informasi dan Transaksi Elektronik). Dimana dasar hukum tersebut menurut beberapa sumber digunakan sebagai media mengkriminalisasi perempuan yang melaporkan kekerasan yang dialaminya yang berdampak pada terhambatnya proses advokasi korban untuk mendapatkan keadilan (Dewi, 2021). Dimana media dan juga publik secara terang terangan membuka kehidupan pribadi GA alih alih menjamin perlindungan terhadap data pribadi miliknya. Masyarkat justru menyudutkan posisinya dengan melakukan penghakiman terhadap moral perempuan. Padahal disisi lain GA merupakan salah satu korban dari Kekerasan Berbasis Gender Online yaitu penyebaran foto maupun video tanpa persetujuannya.

Mengutip dari laman Asumsi.co, dimana salah seorang penyintas revenge porn, mengatakan bahwa ia tak masalah apabila foto dirinya atas persetujuan/izinnya dipajang di galeri kesenian dan dilihat banyak orang. Tapi akan menjadi suatu permasalahan ketika mantan kekasihnya menyebarkan foto dirinya tanpa izin. Asumsi.co menjelaskan bahwa ketika kekuasaan seseorang atas tubuh mereka sendiri telah direnggut, kesehatan mental pun ikut terganggu. Risiko kesehatan mental yang dialami oleh penyintas revenge porn punya kesamaan dengan penyintas perkosaan. Sebagaimana korban kekerasan seksual, korban revenge porn kerap mengalami PTSD (posttraumatic stress disorder), serangan kecemasan, dan depresi. (Dewi, 2021). 
Dengan banyaknya korban KBGO yang terkriminalisasi, maka akan mengurangi jumlah korban KBGO yang ingin bersuara, adanya kekhawatiran jika kejadian tersebut juga menimpa kepadanya. Maka dari itu kini banyak dari lembaga bantuan hukum, lembaga swadaya masyarakat, aktivis perempuan, dan sejumlah mahasiswa/i bahkan para pelajar yang menyuarakan untuk disahkannya RUU PKS. Hal itu karena RUU PKS dirasa dapat menjadi salah satu jalan untuk dapa melindungi dan menjawab kebutuhan korban. Dari sudut pandang hukum, Siti Mazuma Direktur LBH APIK (Lembaga Bantuan Hukum Asosiasi Perempuan Indonesia untuk Keadilan) mengatakan bahwa keengganan korban untuk melapor adalah karena sistem hukum Indonesia yang belum memihak korban. Ketika seorang perempuan telah menjadi korban kekerasan seksual, bukan proses hukum yang akan dikedepankan, tapi orang akan sibuk menyalahkan si korban: "Kenapa enggak lapor? Kenapa diam saja"? begitu kata Zuma, seperti yang dikutip ABC dari Asumsi.co (Iswara, 2021). Selama ini, korban-korban kekerasan seksual dibebankan pada alat bukti. Hal itu karena kasuskasus tersebut berada di wilayah privat, Ada pula faktor keluarga, lingkungan - seperti reaksi victim blaming, persekusi, pemberitaan media yang mengeksploitasi informasi pribadi, kecenderungan lingkungan untuk lebih membela pelaku.

\section{Upaya Perlindungan Korban}

Hukum di Indonesia belum responsif terhadap isu-isu kekerasan berbasis gender, terlebih kompleksitas di ranah digital. Hal ini turut disampaikan pengajar dan peneliti isu gender Lidwina Inge Nurtjahyo yang menggarisbawahi keterbatasan penanggulangan kasus karena tidak tersedianya payung hukum yang dapat melindungi korban. Beberapa bentuk KBGO seperti penyebaran konten intim dan balas dendam dengan pornografi (revenge porn) telah menjadi sedemikian memprihatinkan. Dibutuhkan sensitivitas gender dalam mencermati kasus-kasus ini. Kasus balas dendam dengan pornografi, misalnya, melibatkan pelaku yang pernah memiliki relasi intim dengan korban; pelaku menyebarkan atau menyalahgunakan konten intim yang tersimpan dengan tujuan untuk mencemarkan nama baik korban, memeras korban, hingga mendapatkan keuntungan finansial.

Dengan tingginya intensitas penggunaan ruang digital, semakin mendesak untuk dilakukan sosialisasi kepada masyarakat terkait dengan keamanan digital dan pelindungan privasi sebagai bagian dari hak asasi warga negara. SAFEnet menjelaskan pentingnya dibuat lembaga rujukan yang spesifik diperuntukkan bagi keamanan digital agar masyarakat dapat mengakses informasi dan bantuan seputar hak-haknya di ranah digital (Dewi, 2021). Sementara itu, pemerintah harus memprioritaskan instrumen hukum yang melindungi pengguna, khususnya perempuan yang rentan menjadi korban KBGO, dengan mengesahkan RUU Pungkas (Penghapusan Kekerasan Seksual) dan PDP (Pelindungan Data Pribadi). Diperlukan terobosan hukum untuk mengoreksi maupun menciptakan perangkat hukum baru yang dapat mewujudkan keadilan dan kesetaraan Kemampuan aparat penegak hukum dalam menangani kasus-kasus ini pun masih kurang. Sehingga tak jarang banyak korban justru malah dikriminalisasi karena melapor. Seperti kasus Baiq Nuril, seorang guru yang dipidanakan karena merekam percakapan telepon. Kedudukan mereka adalah sebagai korban, akan tetapi mereka malah mendapatkan tuntutan hukum yang cukup besar atas kasus yang menimpa kepadanya.

Berikut adalah beberapa contoh pasal yang digunakan dalam kasus kekerasan berbasis gender online: 
1. UU ITE Pasal 27 ayat (1) mengatur larangan mendistribusikan, mentransmisikan, dan/atau membuat dapat diaksesnya informasi atau dokumen elektronik yang memiliki muatan yang melanggar kesusilaan.

2. UU Pornografi Pasal 4 ayat (1) mengatur larangan perbuatan memproduksi, membuat, memperbanyak, menggandakan, menyebarluaskan, menyiarkan, mengimpor, mengekspor, menawarkan, memperjualbelikan, menyewakan, atau menyediakan pornografi.

Terlepas dari kekurangan tersebut, ada beberapa tindakan yang bisa dilakukan individu ketika menemukan bahwa dirinya menjadi korban kekerasan berbasis gender online berdasarkan panduan dari SAFENet (Southeast Asia Freeedom of Expression Network), salah satu lembaga swadaya masyarakat yang bergerak di bidang perlindungan hak kebebasan berekspresi dan perlindungan data pribadi di Asia Tenggara. Pertama, korban perlu menyusun kronologi kasusnya untuk keperluan pelaporan; Kedua, menyimpan barang bukti berupa tangkapan layar gambar atau percakapan, rekaman suara atau video; Ketiga memutuskan komunikasi dengan pelaku apabila sudah cukup mengumpulkan bukti. Sebagai tambahan, penting bagi korban untuk melakukan konsultasi psikologis dalam rangka memulihkan dan memperkuat korban selama melakukan proses pelaporan; keempat Pada tahap pelaporan ke jalur hukum, maka penting untuk melakukan pemetaan risiko. Pada tahap ini penting bagi korban dan pendampingnya memetakan opsi penyelesaian kasus dan risiko apa saja yang akan dihadapi korban. Misalnya apabila korban mengajukan laporan ke polisi, maka korban harus siap untuk berhadapan dengan proses interogasi yang cenderung melelahkan dan panjang; Kelima, langkah selanjutnya adalah melaporkan pelaku ke platform digital terkait. Setelah itu, korban mengajukan kasus kepada aparat penegak hukum dengan menyertakan berkas bukti yang telah dikumpulkan (Nurtjahyo, 2020).

\section{KESIMPULAN}

Kekerasan terhadap perempuan dinormalisasi masyarakat yang melekatkan asumsi bahwa tersebarnya data-data intimnya di ranah digital secara nonkonsensual adalah akibat kelalaian dan kecerobohan perempuan. Tak jarang korban dipersalahkan karena tidak berhati-hati dengan data pribadinya. Apabila ditinjau dari prespektif viktimolgi perempuan menurut jenis korban termasuk dalam latent victim.

Penyebab perempuan rentan menjadi korban adalah karena

1. Adanya pandangan bahwa perempuan sebagai makhluk yang lemah, mudah menyerah, lemah fisik dapat memicu perempuan sebagai korban dari revenge porn.

2. Kebanyakan korban membagikan gambar tersebut ke orang yang mereka percaya. Kasus revenge porn sendiri banyak dilakukan oleh mantan kekasih (atau pihak ketiga) yang berusaha menjatuhkan citra perempuan melalui penyebaran foto maupun video porno.

3. Penyebab lain perempuan menajdi korban adalah karena karena gambar atau video mereka diambil secara paksa, seperti komputer mereka diretas atau orang-orang terdekat mereka memaksa mengambil foto mereka.

Perempuan sebagai korban kerap dikriminalisasi, melalui kata-kata dan kalimat yang ada dalam pemberitaan media, hukum, dan publik bahwasanya perempuan dalam satu waktu digambarkan sebagai korban sekaligus pemicu terjadinya kejahatan yang menimpa dirinya. Hal itu karena 
adanya relasi kuasa yang dibentuk dari budaya patriarki ketika perempuan dianggap sebagai kaum inferior dan laki-laki sebagai kaum yang superior.

Hukum di Indonesia belum responsif terhadap isu-isu kekerasan berbasis gender, terlebih kompleksitas di ranah digital. Kasus Kekerasan Berbasis Gender Online hanya didasarkan pada UU ITE dan UU Pornografi yang justru tidak berprespektif pada korban.

\section{DAFTAR PUSTAKA}

Buku

Kamus Besar Bahasa Indonesia. (2002). Jakarta: Balai Pustaka

Lilik,M. (2007). Kapita Selekta Hukum Pidana. Jakarta: Djambatan

Gosita, A. (2004). Masalah Korban Kejahatan. Jakarta:PT Bhuana Ilmu Popular

Mansur,D.,M.,A \& Gultom, E. (2007). Urgensi Perlindungan Korban Kejahatan: Antara Norma dan Realita, Jakarta: PT Rajagrafindo Persada

Muladi. (2005). Hak Asasi Manusia: Hakekat, Konsep dan Implikasinya Dalam Prespektif Hukum Masyarakat. Bandung: Refika Aditama

Mulia,S., M. (2004). Islam Menggugat Poligami. Jakarta: Gramedia Pustaka Utama.

Parera,F.,M. (1990). Tafsir Sosial Atas Kenyataan. Jakarta:LP3ES

Subhan, Z. (2004). Qodrat Perempuan Taqdir atau Mitos. Yogyakarta: Pustaka Pesantren

Sugiyono. (2009). Metode Penelitian Pendidikan Pendekatan Kuantitatif dan R\&D. Bandung:Alfabeta

Widiartana, G. (2014). Viktimologi Prespektif Korban dalam Penanggulangan Kejahatan. Yogyakarta: Cahaya Atma Pustaka

Book

Kusuma,E., Arum,N.,S. Southeast Asia Freadom of Expresion Network (SAFEnet): Sebuah Panduan Memahami dan Menyikapi Kekerasan Berbaasis Gender Online, link: https://www.google.com/url?sa=t\&source=web\&rct=j\&url=https://id.safenet.or.i d/wpcontent/uploads/2019/11/Panduan-KBGO-v2.pdf\&ved=2ahUKEwi69bSJyd 7vAhVu8XMBHSAhCj8QFjAEegQIGBAC\&usg=AOvVaw0w8Xhwcxp1DvK_ $0 \mathrm{G} 6 \mathrm{wr} 7 \mathrm{vF}$

Jurnal

Abdul Munir,M. Karim\&Wulan Junaini. (2020). Studi Terhadap Seorang Prempuan Sebagai Korban Revenge Porn di Pekanbaru. Sisi Lain Realita, 5(01),30

Alfirahmi\&Ekasari,R. (2018). Konstruksi Realitas Sosial Perempuan Tentang Gender Dalam Pembentukan Karakteristik Anak Terhadap Pemahaman Gender. Mediakom: Jurnal Ilmu Komunikasi, 2(2),235

Christian, J., H. (2020). Sekstorsi: Kekerasan Berbasis Gender Online Dalam Paradigma Hukum Indonesia, Jurnal Binamulia Hukum, 9(1), hlm 83-92, https://doi.org/10.37893/jbh.v9i1.103. 
Indrawati. (2015). Trafficking Kejahatan Terhadap Perempuan dan Anak-Anak. Jurnal Cakrawala Hukum, 6(1),39

Marzuki. (2007). Kajian Awal Tentang Teori-Teori Gender, Jurnal Civics, 4(2), hlm 68

Matsuri, S. (2015). The Criminalization of Revenge Porn in Japan," Washington International Law Journal Association, 24(2),289

Paulina, I., I., Rahayu, Dwiwarno, N. (2019). Kewajiban dan TanggungJawab Negara Memberikan Perlindungan Hukum Terhadap Perempuan Korban Revenge Porn di Indonesia. Diponegoro Law Journal, 8(1), hlm. 459

Putri,D.,M.,A. (2012). Blaming The Victim: Representasi Perempuan Korban Pemerkosaan di Media Massa (Analisis Semiotika dalam Pemberitaan di Koran Suara Merdeka Desember 2011-Februari 2012),.Interaksi,1(1),1-15

Website

Adinda,P. (2019). Derita Korban Revenge Porn: Trauma hingga Tak Mendapat Perlindungan Hukum. https://asumsi.co/post/derita-korban-revenge-porn-dari-trauma-hingga-minimnyaperlindungan-hukum (diakses 22 Maret 2021)

Dewi, S. (2021). Membongkar Kekerasan Berbasis Gender Online. https://www.google.com/amp/s/www.jawapos.com/minggu/halte/03/01/2021/me mbongkar-kekerasan-berbasis-gender-online/\%3famp

(diakses 25 Maret 2021)

Iswara, A.,J. (2020). Mengapa Perempuan Korban Pelecehan Seksual Cenderung Enggan https://www.google.com/amp/s/amp.kompas.com/global/read/2020/05/11/210551 670/mengapa-perempuan-korban-pelecehan-seksual-cenderung-enggan-melapor. (diakses 24 Maret 2021)

Nurtjahyo, L.,N. (2020). Kekerasan seksual di internet meningkat selama pandemi dan sasar anak muda: kenali bentuknya dan apa yang bisa dilakukan?https://www.google.com/amp/s/theconversation.com/amp/kekerasan-s eksualdi-internet-meningkat-selama-pandemi-dan-sasar-anak-muda-kenali-bentu knya-dan-apayang-bisa-dilakukan-152230. (diakses 20 Maret 2021)

Saksono, H. Pusat Studi Wanita. http//:www.yahoo.com, diakses 22 Maret 2021

Tim CNN Indonesia,(2021). 1.178 Kasus Kekerasan Perempuan Terjadi Selama 2020. https://m.cnnindonesia.com/gaya-hidup/20210107203520-284-590941/1178-kasu skekerasan-perempuan-terjadi-selama-2020. diakses 22 Maret 2021)

Wantiknas, Akses Digital Meningkat Selama Pandemi. http://www.wantiknas.go.id/id/berita/akses-digital-meningkat-selama-pademi. (diakses 22 Maret 2021)

Undang-Undang

Undang-Undang No 44 Tahun 2008 Tentang Pornografi

Undang-Undang No 19 Tahun 2016 Tentang Informasi dan Transaksi Elektronik 